\title{
The Relationship between School Principals' Leadership Behaviours and Teachers' Job Satisfaction: A Systematic Review
}

\author{
Ramazan Cansoy ${ }^{1}$ \\ ${ }^{1}$ Faculty of Letters, Karabuk University, Karabuk, Turkey \\ Correspondence: Ramazan Cansoy, Faculty of Letters, Karabuk University, Karabuk, Turkey. E-mail: \\ cansoyramazan@gmail.com
}

Received: September 4, 2018

Accepted: October 15, $2018 \quad$ Online Published: December 28, 2018

doi: $10.5539 /$ ies.v $12 \mathrm{n} 1 \mathrm{p} 37$

URL: https://doi.org/10.5539/ies.v12n1p37

\begin{abstract}
This systematic review aims to investigate the relationship between school principals' leadership behaviours and teachers' job satisfaction. With this purpose, studies that focused on this relationship in the literature were examined. Twenty-seven studies found in different databases (i.e. ERIC, WOS, SCOPUS and ULAKBİM) were included in the analysis. These studies mostly focused on the relationships between school principals' transformational and interaction leadership behaviours and teachers' job satisfaction. Additionally, job satisfaction was also studied in relation to servant leadership, ethical leadership, distributive leadership, individual- and task-oriented leadership and school leadership behaviours. Based on the findings of the studies examined, school principals' transformation leadership behaviours were found to have stronger relationships with teachers' job satisfaction compared to interactional leadership behaviours and were an important predictor of job satisfaction. Negative relationships were revealed between laissez-faire leadership and job satisfaction. On the other hand, school principals' servant leadership and ethical leadership behaviours were found to be important variables in ensuring job satisfaction. Lastly, school principals' administrative behaviours that encourage participation and are flexible, sharing leadership at school, and exhibiting individual-oriented and supportive leadership behaviours were revealed to enhance teachers' job satisfaction.
\end{abstract}

Keywords: transformational leadership, leadership approaches, administrative behaviours, school leadership

\section{Introduction}

Within the historical process, theories including the great man theory (1940s-50s), behavioural theory (1950s-60s), probability theory (1960s-70s), situational theory (1964s), transactional theory (1978) and transformational leadership theory (1985) have been influential on the development of leadership (Northouse, 2007). In parallel to this development process, leadership has been addressed in many areas including organisational behaviour, administration, psychology and sociology (Bass \& Avolio, 1993; Bolden, 2004; Bolman \& Deal, 2017; Yukl, 1989). On the other hand, school leadership in education has been a trending research topic since 1960s and 70s (Bass, 1990; Hallinger \& Leithwood, 1994; Hallinger \& Chen, 2015). The understanding of the significance of leadership for school outcomes has guided this strand of research. This is because strong educational leadership was concluded to be effective in carrying out instructional activities flawlessly, improving the cohesion among the staff and enhancing student performance (Cheng, 1994; Griffith, 2004; Hallinger, Bickman, \& Davis, 1996; Hallinger, 2005; Heck, 1992; Marks \& Printy, 2003).

With leadership styles being a research topic in the field of school administration, many scholars studied the effects of leadership styles on the school staff. In this regard, the research on school leadership focused on transformational leadership (Barnett, McCormick \& Conners, 2001; Hallinger, 2003; Griffith, 2004; Koh, Steers \& Terborg, 1995; Leithwood, 1994; Ross \& Gray, 2006), interactional leadership (Nguni, Sleegers \& Denessen, 2006; Silins, 1994), effective leadership (Harris, 2002; Leithwood, Harris \& Hopkins, 2008; Silins, 1992), instructional leadership (Blase \& Blase, 1999; Hallinger, 2005; Marks \& Printy, 2003), distributive leadership (Harris, 2004; Harris \& Spillane, 2008; Heck \& Hallinger, 2009; Spillane, Halverson \& Diamond, 2001), servant leadership (Black, 2010; Cerit, 2009; Fridell, Belcher \& Messner, 2009; Salameh, 2011), authentic leadership (Begley, 2006; Crippen, 2012; Eriksen, 2009) and ethical leadership (Calabrese, 1988; Lashley, 2007; Y1lmaz, 2010).

Initial attempts on leadership theories focused on the roles of leaders and followers, reaching the goals, and 
communication channels. As for current leadership approaches, they examine not only leaders but also followers, supervisors and the workplace environment and culture, thus covering a wide range representing the public and private sectors (Avolio, Walumbwa, \& Weber, 2009). In schools, a particular organisational context, administrators' leadership behaviours and styles were reported to positively affect employees' motivation and performance, organisational justice, school culture and climate, student achievement and job satisfaction, whereas reducing stress, burnout and many organisational behaviours such as the intent to quit work (e.g., Blase, Dedrick, \& Strathe, 1986; Evans, 2001; Friedkin \& Slater, 1994; Griffith, 2004; Hulpia \& Devos, 2009; Leithwood, Menzies, Jantzi, \& Leithwood, 1996; Leithwood \& Jantzi, 2000; Leithwood, Steinbach \& Jantzi, 2002; Marks \& Printy, 2003; Walumbwa, Hartnell, \& Oke, 2010; Y1lmaz \& Altınkurt, 2012). In these studies, the effects of leadership on organisational outcomes were investigated, and it seems that the relationships between leadership and organisational outcomes were addressed quite commonly as a research topic in the literature. Therefore, it is of significance to make sense of the findings of such studies as a whole. In this respect, the present study attempts to analyse the findings reported with regard to the relationships between leadership and job satisfaction in the literature.

\subsection{Theoretical Background}

State Leadership, a concept that has long been studied by researchers, is a complex phenomenon (Avolio, Walumbwa, \& Weber, 2009; Germain, 2012). The complexity of the concept stems from the fact that scholars do not have an agreement regarding its definition (Bass, 1990; Northouse, 2007). Leadership is a phenomenon that is built through social interaction (Avolio, Walumbwa, \& Weber, 2009). More specifically, it is defined in terms of individual characteristics, leadership behaviours, interaction patterns, role relationships, followers' perceptions and effects on followers and the organisational culture (Yukl, 1989). Northouse (2007) states that leadership is a process that appears in a group and includes common goals and influencing followers.

In research studies, leadership is described as a dynamic process, in that the periodic characteristics or behaviours individuals who have characteristics of a leader make it difficult to examine leadership as a whole, and thus prevent researchers from reaching a common definition of the concept (Rost, 1993; Bass, 1990). It can be argued that one of the reasons behind the complexity of leadership is due to the emergence of many different leadership styles such as transformational, interactional, instructional, distributive, ethical, servant and authentic leadership. Demonstrating the definitions of these leadership types can help clarifying this complexity. In this regard, transformational leaders are defined as individuals who raise the interest of individuals in the group by forming a common vision and mission and ensure intellectual stimulation by increasing the motivation of group members (Bass, 1990). Instructional leaders are those administrators who develop educational programs at school and influence the relationship among the stakeholders of school in order to enhance educational achievement (Blase \& Blase, 1999). Distributive leadership is a characteristic related to ensuring collaboration among professional learning communities at school and including them in decision-making processes (Heck \& Hallinger, 2009). Servant leaders are those who do not expect something in return from their followers and are not selfish (Black, 2010). Interactional leadership is about leaders' meeting their followers' requests and expectations in return for their meeting the leader's demands (Silins, 1994). Ethical leadership is the personality characteristic that determines the rules needed to be followed in interpersonal relationships, makes decisions and shares them with employees by communicating with them (Brown, Trevinoand, \& Harrison, 2005). Lastly, authentic leadership is a leadership process based on "knowing one's self and self-awareness" in open relationships with followers (Eriksen, 2009). As can be inferred from different leadership styles in the literature, each style emphasises different characteristics unique to individuals.

In educational research, studies on teachers' job satisfaction were based on theories in areas such as organisation and administration (Kim \& Lodman, 1994; Lester, 1987). Most studies on teachers' job satisfaction associated satisfying factors with the high-level "motivating factors" and low-level "hygen factors" in Herzberg's "dual-factor theory". Motivating factors include intrinsic aspects of a task such as success, recognition, taking responsibility and creating opportunities. Hygiene factors refer to the external problems such as working conditions, control, working policy, salary and interpersonal relationships (Bogler, 2001). Kim and Lodman (1994) state that factors such as low salary, difficulty of working conditions and not having career opportunities negatively affect teachers' job satisfaction, whereas promotion opportunities, professional autonomy and interaction with students and colleagues positively affect their job satisfaction. The effectiveness of education and instruction at school is in a way related to teachers' performance. Teachers' effectiveness refers to their satisfaction with the job and willingness to do their job in accordance with the school goals (Kabaday1, 1982). In a general sense, job satisfaction is the feeling of content and happiness that individuals have while fulfilling a duty (Swaminathan \& Jawahar, 2013). More specifically, teachers' job satisfaction is their positive emotional reactions 
to their job or instructional roles (Skaalvik \& Skaalvik, 2011).

In educational sciences, many studies investigated the relationships between leadership and job satisfaction. Different leadership types including transformational leadership, interactional leadership, laissez-faire leadership, distributive leadership, leadership towards individuals and duties, being a change-centred organisation, servant leadership and ethical leadership were demonstrated to be related to teachers' job satisfaction. Majority of the studies revealed a positive and significant relationship between job satisfaction and different leadership styles. Moreover, leadership behaviours were found to be a predictor of job satisfaction (Bogler, 2001; Eğriboyun, 2015; Ereş \& Akyürek, 2016; Hulpia, Devos, \& Rosseel, 2009; Karadağ, Başaran, \& Korkmaz, 2009; Yılmaz \& Ceylan, 2011).

School administrators' leadership is related to guiding teachers, implementing plans and motivating teachers. Job satisfaction, on the other hand, denotes employees' perceptions of the workplace, their relationships with colleagues, income and promotion opportunities. Many factors' including school administrators' leadership style, demographic characteristics and workplace environment can effect employees' job satisfaction. In this regard, there seems to be no overall evaluation of the studies on the relationship between school administrators' leadership and teachers' job satisfaction in Turkey, and thus the research findings in the existing literature were not demonstrated and analysed as a whole in detail. This study is believed to guide further attempts on the theory, research and practice that would reveal the relationship between leadership and job satisfaction. Accordingly, the aim of this study was to examine the relationship between leadership and job satisfaction through the systematic review method and gather the findings of individual studies determined based on various criteria. More specifically, it was aimed to reveal the common findings in studies on the relationship between school principals' leadership behaviours and teachers' job satisfaction.

\section{Method}

This study aimed at analysing the studies on the relationships between school administrators' leadership behaviours/styles and teachers' job satisfaction in the field of education through a systematic review. Systematic review refers to synthesising the findings of many different studies in a way that is clear, transparent, replicable and accountable (Oakley, 2002). Systematic review is not merely a literature review, but a method that is used to address a research question. It helps summarise comprehensive research-based information that can be used by both practitioners and decision-makers and policy-makers (Brettle, 2009).

\subsection{Research Strategy and Data Sources}

It is the study was conducted within respectable data bases containing journals in the field of educational sciences. Accordingly, the studies examined in this work consisted of original articles searched in Web of Science, ERIC, SCOPUS and ULAKBIM data bases.

\subsection{Criteria for the Selection of Studies}

The criteria adopted in the selection of studies is as follows: (1) being published in refereed-journals, (2), being published between 2000-2017, (3) focusing on the relationship between school administrators' leadership and teachers' job satisfaction, (4) being conducted at primary and high school levels, (5) employing quantitative research methods, (6) the language of publication being English or Turkish.

\subsection{Obtaining the Studies}

The studies that met the inclusion criteria in the data bases were downloaded and saved. Those that were conducted at higher education level, or in public or business administration were excluded from the analysis. The abstract of the studies were read and reviewed by the researchers. These studies were categorised as focusing on (a) the relationship between school administrators' leadership characteristics and teachers' job satisfaction, (b) school administrators' leadership characteristics as a predictor of teachers' job satisfaction. Data searching process is presented in Figure 1. 


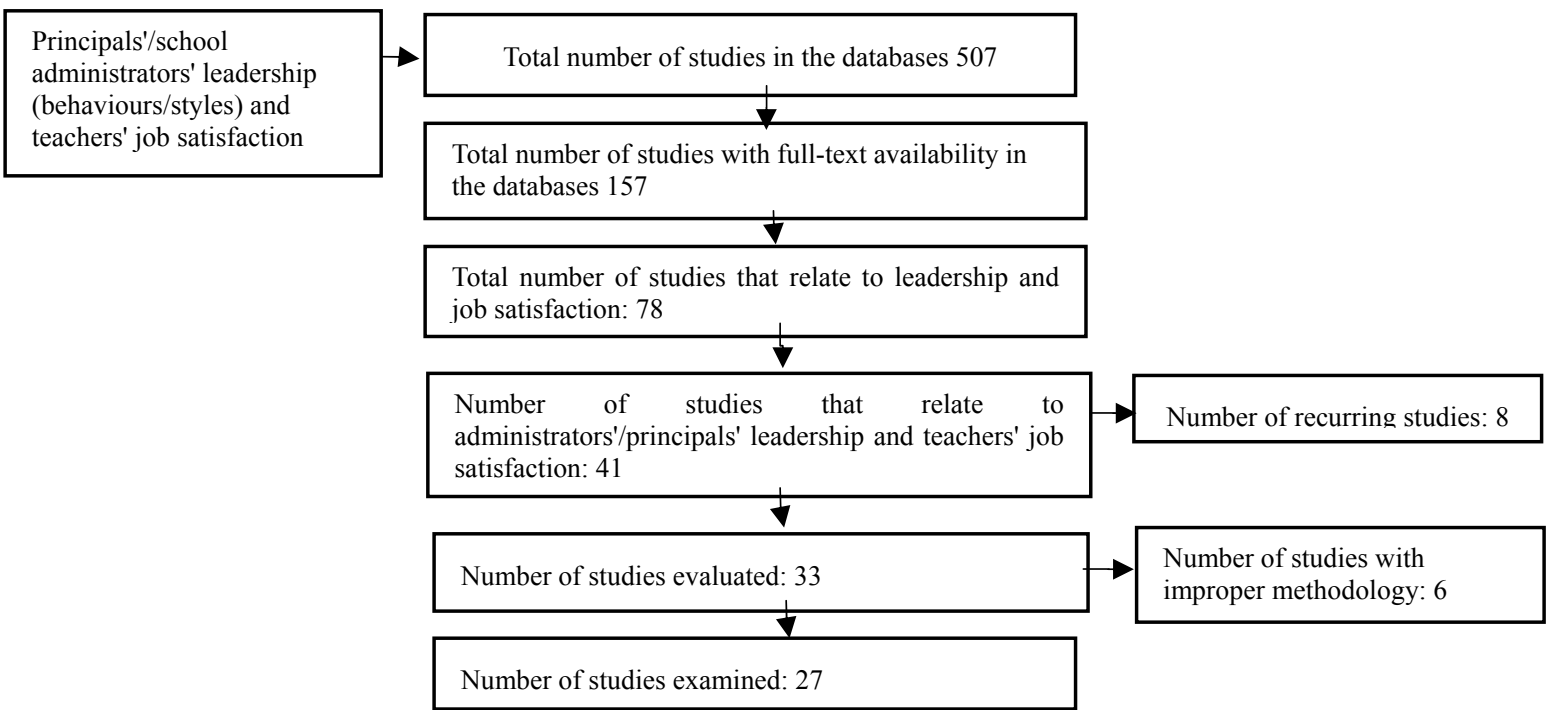

Figure 1. Data searching process of the study

\subsection{Quality of the Studies}

Twelve of the studies were conducted in elementary, middle and high schools in Turkey, whereas the remaining 15 studies were carried out in Oman $(n=2)$, China $(n=2)$, Indonesia $(n=2)$, Belgium $(n=1)$, Italy $(n=1)$, Tanzania $(n=2)$, Iran $(n=2)$, Israel $(n=2)$, the USA $(n=1)$ and India $(n=1)$. Twenty-four of the studies focused on only teachers, while three gathered data from both teachers and principals. As for the distribution of the studies by year, nearly $63 \%$ were conducted after 2014, which indicates an increase after this year. The remaining ten studies were carried out between 2001 and 2013. Four of the studies in Turkey were conducted after 2014. It can thus be said that the interest on the relationship between leadership behaviours and job satisfaction increased after 2014.

\subsection{Measurement Tools and Their Quality}

In the studies examined, 12 different measurement tools were employed to measure school administrators' leadership behaviours. In almost half of the studies, the Multifactor Leadership Questionnaire (MLQ) was used. In two studies, questionnaires on transformation leadership styles developed by different scholars or the researchers themselves were employed. Additionally, questionnaires related to distributive leadership, servant leadership, ethical leadership, school leadership and leadership behaviours were also used. In most of the studies, the Cronbach's Alpha values were found to be .70 and above. The researchers often re-tested the reliability values in their own samples or reported values from similar studies. In two studies, reliabilities values were not presented, and in two other studies, the values of the researchers who developed the measurement tools were given. On the other hand, job satisfaction was measured by means of 20 different measurement tools. The Minnesota Job Satisfaction Questionnaire developed by (Weiss, Dawis, England \& Lofquist, 1967) and the Job Satisfction Scale developed by Spector (1985) were mostly employed in the studies. The Cronbach's Alpha values of the measurement tools were reported to be .70 and above. Regression and correlation analyses were frequently performed in the studies. Structural equation modelling was also used, though rarely. Convenient sampling was commonly preferred. Consequently, the studies seem to have a certain level of quality since reporting reliability values are seen as important to appropriately interpret findings.

\section{Results}

In the studies examined, eight different leadership styles were demonstrated to be related to teachers' job satisfaction. These styles are transformational leadership, interactional leadership, laissez-faire leadership, distributive leadership, leadership towards individuals and duties, being a change-centred organisation, servant leadership and ethical leadership. Majority of the studies revealed a positive and significant relationship between job satisfaction and different leadership styles. Moreover, leadership behaviours were also found to be a predictor of job satisfaction (see Table 1). The summarised findings of the studies examined are presented below. 
Table 1. Relationships between leadership behaviours and job satisfaction

\begin{tabular}{|c|c|c|c|}
\hline & Leadership behaviours & Source & $\begin{array}{l}\text { Relationship } \\
\text { with job } \\
\text { satisfaction }\end{array}$ \\
\hline \multirow{12}{*}{ 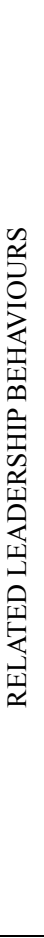 } & $\begin{array}{l}\text { Transformational } \\
\text { leadership }\end{array}$ & $\begin{array}{l}\text { Bogler (2001), Eğriboyun (2015), Griffith (2004), Haj \& Jubran (2016), Hariri, } \\
\text { Monypenny \& Prideaux (2016), Karadağ, Başaran \& Korkmaz (2009), Korkmaz } \\
\text { (2007), Nasra \& Heilbrunn (2016), Nguni, Sleegers \& Denessen (2006), Sayadi } \\
\text { (2016), Teswaf (2014), Tok \& Bacak (2013), Kadi (2015), Nyenyembe, Maslowski, } \\
\text { Nimrod \& Peter (2016) }\end{array}$ & + \\
\hline & & Dutta \& Sahney (2016) & No relationship \\
\hline & & Korkmaz (2007) & No relationship \\
\hline & Interactional leadership & $\begin{array}{l}\text { Eğriboyun (2015), Karadağ, Başaran \& Korkmaz (2009), Nguni, Sleegers \& Denessen } \\
\text { (2006), Kadi (2015) }\end{array}$ & + \\
\hline & & Bogler (2001) & - \\
\hline & Laissez-faire leadership & Hariri, Monypenny \& Prideaux (2016), Sayadi (2016), Kadi (2015) & - \\
\hline & Distributive leadership & Bogler (2001), Hulpia, Devos \& Rosseel (2009), Ereş \& Akyürek (2016) & + \\
\hline & $\begin{array}{l}\text { Leadership towards } \\
\text { individuals and duties }\end{array}$ & Y1lmaz \& Ceylan (2011), Taş (2017) & + \\
\hline & $\begin{array}{l}\text { Being a change-centred } \\
\text { organisation }\end{array}$ & Paletta, Alivernini \& Manganelli (2017), Taş (2017) & + \\
\hline & Servant leadership & Zhang, Lee \& Wong (2016), Cerit (2009), Al-Mahdy, Al-Harti \& El-Din, 2016) & + \\
\hline & Ethical leadership & $\begin{array}{l}\text { Güngör (2016), Madenoğlu, Uysal, Sarıer, Banoğlu (2014) } \\
\text { Çetin \& Özcan (2004) }\end{array}$ & + \\
\hline & $\begin{array}{l}\text { Making participating } \\
\text { decisions }\end{array}$ & Bogler, 2001, Hulpia, Devos \& Rosseel, 2009, Hariri, Monypenny \& Prideaux, 2016 & + \\
\hline \multirow{15}{*}{ 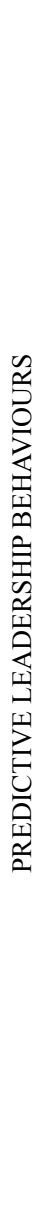 } & $\begin{array}{l}\text { Transformational } \\
\text { leadership }\end{array}$ & $\begin{array}{l}\text { Korkmaz (2007), Bogler (2001), Griffith (2004), Nguni et al., (2006), Nasra \& } \\
\text { Heilbrunn (2016), Hariri, Monypenny \& Prideaux, } 2016\end{array}$ & $\begin{array}{l}\text { Predictor } \\
\text { Variable }\end{array}$ \\
\hline & Idealised effect & Sayadi (2016), Teswaf (2014), Nyenyembe et al. (2016), Nguni et al. (2006) & $\begin{array}{l}\text { Predictor } \\
\text { Variable }\end{array}$ \\
\hline & Inspirational motivation & Teswaf (2014) & $\begin{array}{l}\text { Predictor } \\
\text { Variable }\end{array}$ \\
\hline & Individual interest & Nyenyembe et al. (2016) & $\begin{array}{l}\text { Predictor } \\
\text { Variable }\end{array}$ \\
\hline & Intellectual stimulation & Nguni et al. (2006) & $\begin{array}{l}\text { Predictor } \\
\text { Variable }\end{array}$ \\
\hline & Interactional leadership & Bogler (2001) & $\begin{array}{l}\text { Predictor } \\
\text { Variable }\end{array}$ \\
\hline & Conditional rewards & Nguni et al. (2006) & $\begin{array}{l}\text { Predictor } \\
\text { Variable }\end{array}$ \\
\hline & School leadership & Paletta et al. (2017) & $\begin{array}{l}\text { Predictor } \\
\text { Variable }\end{array}$ \\
\hline & $\begin{array}{l}\text { Individual-oriented } \\
\text { leadership }\end{array}$ & Taş (2017); Cerit (2009) & $\begin{array}{l}\text { Predictor } \\
\text { Variable }\end{array}$ \\
\hline & Leader-team cohesion & Hulpia et al., 2009 & $\begin{array}{l}\text { Predictor } \\
\text { Variable }\end{array}$ \\
\hline & Supportive leadership & Hulpia et al., 2009; Cerit (2010) & $\begin{array}{l}\text { Predictor } \\
\text { Variable }\end{array}$ \\
\hline & $\begin{array}{l}\text { Rational } \\
\text { decision-making }\end{array}$ & Hariri et al. (2012) & $\begin{array}{l}\text { Predictor } \\
\text { Variable }\end{array}$ \\
\hline & $\begin{array}{l}\text { Dependent } \\
\text { decision-making }\end{array}$ & Hariri et al. (2012) & $\begin{array}{l}\text { Predictor } \\
\text { Variable }\end{array}$ \\
\hline & $\begin{array}{ll}\text { Servant leadership } \\
\text { behaviours }\end{array}$ & Zhang, Lee \& Wong (2016); Cerit (2009) & $\begin{array}{l}\text { Predictor } \\
\text { Variable }\end{array}$ \\
\hline & Authentic acts & Cerit (2009) & Predictor \\
\hline
\end{tabular}




\begin{tabular}{llll}
\hline & & Variable \\
\hline Ethical leadership & Güngör (2016); Madenoğlu, Uysal, Sarıer, Banoğlu (2014) & Predictor \\
Variable &
\end{tabular}

Provide fifteen studies focused on the relationships between transformational leadership and job satisfaction. In fourteen of these studies, school principals' transformational leadership behaviours were found to be positively and significantly related to job satisfaction (Bogler, 2001; Eğriboyun, 2015; Griffith, 2004; Haj \& Jubran, 2016; Hariri, Monypenny, \& Prideaux 2016; Kadi, 2015; Karadağ, Başaran, \& Korkmaz 2009; Korkmaz, 2007; Nasra \& Heilbrunn, 2016; Nguni, Sleegers, \& Denessen, 2006; Nyenyembe, Maslowski, Nimrod, \& Peter, 2016; Sayadi, 2016; Teswaf, 2014; Tok \& Bacak, 2013). Furthermore, there are findings that indicate the predictive strength of transformational leadership in explaining job satisfaction. In three of the studies that revealed such findings, transformational leadership was a strong predictor of job satisfaction (Griffith, 2004; Korkmaz, 2007; Nasra \& Heilbrunn, 2016). In three other studies, transformational leadership was founud to have weaker predictive levels (Bogler, 2001; Hariri, Monypenny, \& Prideaux, 2016; Nguni, Sleegers, \& Denessen, 2006). Unlike these findings, transformational leadership and job satisfaction were not found to be related in one study (Dutta \& Sahney, 2016). On the other hand, there are studies that examined job satisfaction as intrinsic and extrinsic job satisfaction. In these studies, the relationships between transformational leadership and intrinsic and extrinsic job satisfaction were positive and significant (Karadağ, Başaran, \& Korkmaz, 2009; Korkmaz, 2007; Teswaf, 2014). These findings as a whole show that school administrators' transformational leadership behaviours can be antecedents of teachers' job satisfactions. In this regard, it can be argued that as school administrators' transformational leadership behaviours increase, teachers' job satisfaction also increases.

In the studies examined, transformational leadership was often examined with its dimensions including charismatic or idealised effect, inspirational motivation, intellectual stimulation and individual interest. Among these dimensions, idealised effect was founud to be positively and significantly related to job satisfaction at higher levels (Nyenyembe, Maslowski, Nimrod, \& Peter, 2016; Sayadi, 2016; Teswaf, 2014). Besides, idealised effect was reported to be an important predictor of teachers' job satisfaction (Nyenyembe et al., 2016; Sayadi, 2016; Teswaf, 2014). Moreover, the dimension of individual interest was found to be positively and significantly related to job satisfaction (Nyenyembe et al., 2016; Sayadi, 2016; Teswaf, 2014; Tok \& Bacak, 2013). Likewise, Nyenyembe et al. (2016) stated that individual interest was an important predictor of job satisfaction. Lastly, in three studies, intellectual stimulation was reported to have positive and significant relationships with job satisfaction (Sayadi, 2016; Teswaf, 2014; Tok \& Bacak, 2013). Similarly, forming an influential vision at school (Ereş \& Akyürek, 2016; Hulpia, Devos, \& Rosseel, 2009; Paletta, 2017), and inspirationally motivating behaviours were found to be related to (Tok \& Bacak, 2013), and to be a predictor of (Teswaf, 2014), teachers' job satisfaction. These findings demonstrate that the dimensions of transformational leadership including charismatic or idealised effect, inspirational motivation, intellectual stimulation and individual interest are important leadership behaviours for promoting teachers' job satisfaction.

In four of the studies reporting a relationship between interactional leadership and job satisfaction, a significant and positive relationship were revealed (Eğriboyun, 2015; Karadağ, Başaran, \& Korkmaz, 2009; Kadi, 2015; Nguni, Sleegers, \& Denessen, 2006). Nguni et al. (2006) found that interactional leadership explained $4 \%$ of the variation in job satisfaction. However, Bogler (2001) revealed a negative relationship between interactional leadership and job satisfaction, while Korkmaz (2007) demonstrated that these two variables were not significantly related. As for the subdimensions of interactional leadership, Nguni, Sleegers, and Denessen (2006) indicated that the dimension "management with exceptions (passive)" was a predictor of job satisfaction. Unlike this finding, Nyenyembe, Maslowski, Nimrod, and Peter (2016) found that the dimension "management with exceptions (passive)" was a negative predictor of job satisfaction. Sayadi (2016) reported that there was no significant relationship between the dimension "management with exceptions (passive)" and job satisfaction. In Nguni et al. (2006) and Sayadi (2016), conditional rewards and job satisfaction were observed to be related. Nguni et al. (2016) noted that conditional rewards were also a predictor of job satisfaction. Kadi (2015) indicated that laissez-faire leadership had a negative and significant relationship with job satisfaction. Hariri, Monypenny and Prideaux (2016) discovered that laissez-faire leadership predicted job satisfaction at a weak and negative level. An opposite finding was revealed in another study (Karadağ, Başaran, \& Korkmaz, 2009). Although there is evidence showing a relationship between interactional leadership and job satisfaction, there seems to be an inconsistency between the findings reported in the literature. Yet, it can be argued that interactional leadership and its subdimensions are related to to job satisfaction, weakly though.

Leadership behaviours that feature participative approaches at school and sharing the authority and 
responsibilities were reported to predict teachers' job satisfaction (Bogler, 2001; Hulpia, Devos, \& Rosseel, 2009; Ereş \& Akyürek, 2016). Hulpia, Devos, and Rosseel (2009) and Ereş and Akyürek (2016) found that supportive leadership style was positively related to job satisfaction. Teachers' job satisfaction was also revealed to increase with the presence of a harmonious team work (Hulpia, Devos, \& Rossel, 2009). Moreover, school principals' dependent decision-making strategies, which relates to making decisions with other members of the school, predicted job satisfaction (Hariri, Monypenny, \& Prideaux, 2016). Consistently, there are also studies that show a relationship between school principals' decision-making strategies and teachers' job satisfaction. In these studies, intuitive and avoidant decision-making was found to negatively predict job satisfaction (Hariri, Monypenny, \& Prideaux, 2012, 2016).

In two studies, leadership behaviours towards individuals and duties were reported to be related to job satisfaction (Taş, 2017; Yılmaz \& Ceylan, 2011). Yılmaz and Ceylan (2011) stated that when leadership behaviours are towards both individuals and duties, they are strongly related to job satisfaction. Likewise, Taş (2017) demonstrated that organisation-oriented and individual-oriented leadership were positively and strongly related to job satisfaction.

Three different studies reported findings regarding the relationship between servant leadership and job satisfaction (Al-Mahdy, Al-Harti, \& El-Din, 2016; Cerit, 2009; Zhang, Lee, \& Wong, 2016). Zhang, Lee and Wong (2016) revealed that school administrators' servant leadership behaviours explained $22 \%$ of the variation in teachers' job satisfaction, while Cerit (2009) observed this figure as 58\%. Cerit (2009) also found that administrators' authentic behaviours were stronger predictors of intrinsic and extrinsic job satisfaction. Al-Mahdy, Al-Harti, and El-Din (2016) discovered positive and strong relationships between supervision towards improving team skills, a servant leadership dimension, and job satisfaction.

Three studies investigated the relationship between school principals' ethical leadership behaviours and job satisfaction (Çetin \& Özcan, 2004; Güngör, 2016; Madenoğlu, Uysal, Sarıer, \& Banoğlu, 2014). In two of these studies, Güngör (2016) and Madenoğlu, Uysal, Sarıer and Banoğlu (2014) indicated that ethical leadership could explain job satisfaction, and there were positive moderate correlations in-between. In the third study, Çetin and Özcan (2004) stated that ethical behaviours including tolerance, justice, honest, democracy and respect were positively and significantly related to teachers' job satisfaction.

Table 2. School principals' leadership behaviours that relate to teachers' job satisfaction, and the levels of relationships

\begin{tabular}{|c|c|}
\hline & \\
\hline $\begin{array}{l}\text { Characteristics that are strongly related to teachers' job satisfaction } \\
\text { (Correlation coefficient }>0.5 \text { ) } \\
\text { Transformational leadership, idealised effect, interactional leadership, } \\
\text { charisma, organisation-oriented leadership, individual-oriented leadership, } \\
\text { change-oriented leadership, rational decision-making, strong vision, } \\
\text { leader-team cohesion, servant leadership, developmental supervision, } \\
\text { ethical leadership, school leadership }\end{array}$ & $\begin{array}{l}\text { Al-Mahdy, Al-Harti \& El-Din (2016), Bogler (2001), Cerit } \\
\text { (2009), Ereş \& Akyürek (2016), Eğriboyun (2015), Griffith } \\
\text { (2004), Güngör (2016), Haj \& Jubran (2016), Korkmaz } \\
\text { (2007), Madenoğlu, Uysal, Sarıer, Banoğlu (2014), Nasra \& } \\
\text { Heilbrunn (2016), Nyenyembe, Maslowski, Nimrod \& Peter } \\
\text { (2016), Teswaf (2014), Kadi (2015), Taş (2017), Hariri, } \\
\text { Monypenny \& Prideaux (2012) }\end{array}$ \\
\hline $\begin{array}{l}\text { Characteristics that are moderately related to teachers' job satisfaction } \\
\text { (Correlation coefficient between 0.2-0.5) } \\
\text { Transformational leadership, interactional leadership, inspirational } \\
\text { motivation, participative leadership, idealised effect, individual interest, } \\
\text { intellectual stimulation, conditional rewards, individual-oriented leadership, } \\
\text { rational decision-making strategies, dependent decision-making, valuing } \\
\text { individuals, improving individuals, forming a community, authentic acts, } \\
\text { improving leadership, ethical leadership behaviours, servant leadership }\end{array}$ & $\begin{array}{l}\text { Karadağ, Başaran \& Korkmaz (2009), Bogler (2001), Cerit } \\
\text { (2009), Çetin \& Özcan (2004), Eğriboyun (2015), Hariri, } \\
\text { Monypenny \& Prideaux (2012), Kadi (2015), Nguni, Sleegers } \\
\text { \& Denessen (2006), Nyenyembe, Maslowski, Nimrod \& Peter } \\
\text { (2016), Sayadi (2016), Yılmaz \& Ceylan (2011), Tok \& Bacak } \\
\text { (2013), Teswaf (2014), Taş (2017). }\end{array}$ \\
\hline $\begin{array}{l}\text { Characteristics that are weakly related to teachers' job satisfaction } \\
\text { (Correlation coefficient }<0.2 \text { ) } \\
\text { Transformational leadership, individual interest, dependent decision-making } \\
\text { strategy }\end{array}$ & $\begin{array}{l}\text { Hariri, Monypenny \& Prideaux (2012), Nyenyembe, } \\
\text { Maslowski, Nimrod \& Peter (2016), Tok \& Bacak (2013) }\end{array}$ \\
\hline
\end{tabular}

Table 2 demonstrates the relationships between teachers' job satisfaction and school principals' administrative behaviours at different levels. Leadership behaviours or its subdimensions revealed strong, moderate or weak relationships. In overall, job satisfaction had moderate and strong relationships with leadership behaviours. On the 
other hand, the findings of the studies in the Turkish context (e.g. Kadi, 2015; Korkmaz, 2007) had parallels with those reported in the international literature (e.g. Hariri, Monypenny, \& Prideaux, 2012).

\section{Discussion}

This study aimed at analysing the findings of 27 studies that examined the relationships between school principals' different leadership behaviours and teachers' job satisfaction. The studies mostly focused on transformational leadership behaviours among basic leadership characteristics. In their meta-analysis, Aydın, Sarıer and Uysal (2013) found that transformational leadership had a positive influence on teachers' job satisfaction and organisational commitment. They also concluded that as administrators' leadership behaviours evolved from transaction to transformation, teachers' organisational commitment and job satisfaction increased. In a similar vein, Leithwood and Jantzi (2005) found in the studies they examined that transformational leadership had an effect particularly on student achievement and students' participation in school. They indicated that transformational school leadership was influential on variables including teachers' commitment and job satisfaction. Likewise, in their meta-analysis on transformational leadership and employees' performance, Wang, Oh, Courtright and Colbert (2011) demonstrated that this leadership style was positively related to followers' performance, job satisfaction and commitment. In another meta-analysis study, Chin (2007) reported that transformational school leadership had a positive effect on teachers' job satisfaction, school effectiveness and student achievement in schools where school administrators exhibit this leadership style.

In the studies, interactional leadership was found to be insignificant leadership characteristic in enhancing job satisfaction. Moreover, there are common findings showing that job satisfaction can decrease with laissez-faire leadership behaviours. In parallel to these findings, Özgözgü and Altunay (2016) determined that transformational, instructional and interactional leadership behaviours were influential on school effectiveness according to teachers' views, and the relationship between interactional leadership and job satisfaction was weak. Cummings et al. (2009) revealed in many studies they examined that administrators' leadership styles (e.g. transformational, resonance, supportive and evaluative) being human- and relationship-focused was strongly related to nurses' job satisfaction. Yet, some studies reported that leadership styles focused on duties and duty-focused leadership styles (e.g. incompatible and instrumental management) had weak relationships with job satisfaction. Besides, the studies revealed the common finding that servant leadership, ethical leadership and distributive leadership were potential leadership behaviours that can promote job satisfaction. In this respect, Parris and Peachey (2013) determined that servant leadership contributed to employees' content and job satisfaction. Therefore, it was concluded in this study that administrators' behaviours in which they synthesize servant, ethical and distributive leadership characteristics at the centre of transformational leadership would highly contribute to teachers' job satisfaction. Cowden, Cummings, and Profetto-Mcgrath (2011) examined the studies on leadership practices and nurses intent to stay in the job. Early studies concentrated on administrators' leadership styles and powers while later studies evolved towards leaders' interactions and communications with their employees (e.g. transformational and relational leadership), rather than individual leadership characteristics. In their systematic review on school leadership in Asian countries, Hallinger and Chen (2015) argued that there was a heavy trend in organisational behaviour in education and change and development at school.

School principals' valuing employees and showing them interest, strengthening justice and confidence in interactions throughout school processes, and creating a strong vision around common goals and a sincere school atmosphere can positively affect job satisfaction. Furthermore, a participative, flexible and facilitative structure of administration, strong administrator support, open communication channels, mutual understanding and a school atmosphere where participation is encouraged are seen among important leadership behaviours for promoting job satisfaction. Accordingly, it can be argued that the leadership behaviours that enhance teachers' job satisfaction are mostly individual-oriented leadership behaviours that meet psychological needs, highlight humanistic, social and ethical values, and provide opportunities for self-realization. In this review of the studies on the effects of satisfaction with the leader and leadership behaviours on employee satisfaction in the field of administration, Skakon, Nielsen, Borg, and Guzman (2010) found that satisfaction with the leader or leadership behaviours positively affected employees' happiness and job satisfaction while negative leadership behaviours caused stress, burnout and dissatisfaction in employees. In another systematic review, Belias and Koustelios (2014) asserted that followers' needs were considered in measurement tools regarding leadership, and leadership characteristics such as mutual trust, respect, inspiration and communication between supervisors and followers, ensuring motivation, effectiveness and development were taken into consideration. For this reason, effective leaders who possess these characteristics are more likely to contribute to their employees' performance and job satisfaction.

Fifteen of the 27 studies examined revealed relationships between transformational leadership behaviours and job satisfaction. It can thus be stated that the theory related to transformational leadership was sufficiently tested in the 
context of schools. However, it seems that the relationships between servants, ethical and distributive leadership and job satisfaction were not tested to the same extent, and there is a need for new studies. Findings that are parallel to these can be encountered in the literature. In this sense, Coomber and Barriball (2007) found in their review that stress and leadership problems were influential on job satisfaction and intent to leave work. In their review on the relationship between leadership and employee health, Kuoppala, Lamminpa, Liira, and Vainio (2008) determined that leadership had an important role in employees' job satisfaction and occupational health. Testing whether the leadership behaviours mentioned above are important variables in ensuring teachers' job satisfaction may provide important insights for developing certain leadership behaviours. As a matter of fact, Kim (2009) stated that leadership transformed a traditional hierarchical structure into participative administration, strengthened the staff and thus enhanced job satisfaction. Cogaltay, Yalcin, and Karadag (2016) found in the studies they examined that positive leadership behaviours positively affected job satisfaction, whereas negative leadership behaviours reduced satisfaction with the job. As a result, the studies generally reported that school principals' leadership styles and behaviours were related to teachers' job satisfaction and were a potential variable for promoting job satisfaction.

\section{Recommendations}

\subsection{Suggestions for Practitioners}

Based on the findings presented above, it can be suggested that school principals should have mutual communication with teachers, help and support them, exhibit behaviours based on justice, equality and honesty, create a strong vision around common objectives, share school-related tasks with employees, and improve their skills. Moreover, they should make effort to form a strong school culture where there is participation, flexibility and healthy and open communication. In this way, teachers can be enabled to enjoy their job and perform higher quality work.

\subsection{Suggestions for Further Research}

The relationships between school principals' leadership behaviours and teachers' job satisfaction seem to have centred upon transformational leadership. However, research on the relationships between servant, ethical and distributive leadership and job satisfaction has been limited. Furthermore, the available research was mostly conducted in the international literature after 2014. Therefore, the relationships between these leadership styles and job satisfaction can be tested in different school settings so as to expend the current literature. Similar reviews can also be carried out with the theses/dissertations written in Turkey. Additionally, job satisfaction and administrators' leadership behaviours can be examined in terms of mediator variables. In some of the studies examined, reliability values were not reported for the measurement tools. In this regard, researchers can be more careful to enhance the reliability of their research. On the other hand, there are various measurement tools related to job satisfaction in particular. Such relationships can be tested by means of widely-accepted measurement tools that are available in the literature. Similar studies can be examined in terms of leadership and different organisational outcomes.

\section{References}

Al-Mahdy, Y. F., Al-Harthi, A. S., \& Salah El-Din, N. S. (2016). Perceptions of school principals' servant leadership and their teachers' job satisfaction in Oman. Leadership and Policy in Schools, 15(4), 543-566. https://doi.org/10.1080/15700763.2015.1047032

Avolio, B. J., Walumbwa, F. O., \& Weber, T. J. (2009). Leadership: Current theories, research, and future $\begin{array}{lllll}\text { directions. Annual } & \text { Review }\end{array}$ https://doi.org/10.1146/annurev.psych.60.110707.163621

Aydın, A., Sarıer, Y., \& Uysal, Ş. (2013). Okul müdürlerinin liderlik stillerinin, öğretmenlerin örgütsel bağlılığına ve iş doyumuna etkisi. Kuram ve Uygulamada Eğitim Bilimleri, 13(2), 795-811.

Barnett, K., McCormick, J., \& Conners, R. (2001). Transformational leadership in schools-panacea, placebo or problem? Journal of Educational Administration, 39(1), 24-46. https://doi.org/10.1108/09578230110366892

Bass, B. M. (1990). From transactional to transformational leadership: Learning to share the vision. Organizational Dynamics, 18(3), 19-31.

Bass, B. M., \& Avolio, B. J. (1993). Transformational leadership and organizational culture. Public Administration Quarterly, 112-121.

Begley, P. T. (2006). Self-knowledge, capacity and sensitivity: Prerequisites to authentic leadership by school 
$\begin{array}{llll}\text { principals. Journal of Educational } & \text { Administration, }\end{array}$ https://doi.org/10.1108/09578230110366892

Belias, D., \& Koustelios, A. (2014). Leadership and job satisfaction-A review. European Scientific Journal, $10(8), 24-46$.

Black, G. L. (2010). Correlational analysis of servant leadership and school climate. Catholic Education: A Journal of Inquiry and Practice, 13(4), 437-466. https://doi.org/10.15365/joce.1304032013

Blase, J., \& Blase, J. (1999). Principals' instructional leadership and teacher development: Teachers' perspectives. Educational Administration Quarterly, 35(3), 349-378. https://doi.org/10.1177/0013161X99353003

Blase, J., Dedrick, C., \& Strathe, M. (1986). Leadership behavior of school principals in relation to teacher stress, satisfaction, and performance. The Journal of Humanistic Counseling, 24(4), 159-171. https://doi.org/10.1002/j.2164-4683.1986.tb00290.x

Bogler, R. (2001). The influence of leadership style on teacher job satisfaction. Educational Administration Quarterly, 37(5), 662-683. https://doi.org/10.1177/00131610121969460

Bolden, R. (2004). What is leadership? Leadership south west research report. Centre for Leadership Studies, Exeter, UK.

Bolman, L. G., \& Deal, T. E. (2017). Reframing organizations: Artistry, choice, and leadership. New Jersey, John Wiley \& Sons.

Brettle, A. (2009). Systematic reviews and evidence-based library and information practice. Evidence Based Library and Information Practice, 4(1), 43-50.

Brown, M., Trevino L., \& Harrison D. (2005). Ethical Leadership, a social learning perspective for construct development and testing. Organizational Behavior and Human Decision Processes, 97, 117-134. https://doi.org/10.1016/j.obhdp.2005.03.002

Calabrese, R. L. (1988). Ethical leadership: A prerequisite for effective schools. NASSP Bulletin, 72(512), 1-4. https://doi.org/10.1177/019263658807251201

Cerit, Y. (2009). The effects of servant leadership behaviours of school principals on teachers' job satisfaction. Educational Management Administration \& Leadership, 37(5), 600-623. https://doi.org/10.1177/1741143209339650

Çetin, M., \& Özcan, K. (2004). Okul yöneticilerinin etik davranışlarının öğretmenlerin iş doyumuna etkisi [The effect of school administrators' ethical behaviours on teachers' job satisfaction]. M.Ü. Atatürk Eğitim Fakültesi Eğitim Bilimleri Dergisi, 20, 21-38.

Chin, J. M. C. (2007). Meta-analysis of transformational school leadership effects on school outcomes in Taiwan and the USA. Asia Pacific Education Review, 8(2), 166-177. https://doi.org/10.1007/BF03029253

Cogaltay, N., Yalcin, M., \& Karadag, E. (2016). Educational leadership and job satisfaction of teachers: A meta-analysis study on the studies published between 2000 and 2016 in Turkey. Eurasian Journal of Educational Research, 16(62), 255-282. http://dx.doi.org/10.14689/ejer.2016.62.13

Coomber, B., \& Barriball, K. L. (2007). Impact of job satisfaction components on intent to leave and turnover for hospital-based nurses: A review of the research literature. International Journal of Nursing Studies, 44(2), 297-314. https://doi.org/10.1016/j.ijnurstu.2006.02.004

Cowden, T., Cummings, G., \& Profetto-Mcgrath, J. (2011). Leadership practices and staff nurses' intent to stay: a systematic review. Journal of Nursing Management, 19(4), 461-477. https://doi.org/10.1111/j.1365-2834.2011.01209.x

Crippen, C. (2012). Enhancing authentic leadership-followership: Strengthening school relationships. Management in Education, 26(4), 192-198. https://doi.org/10.1177/0892020612439084

Cummings, G. G., MacGregor, T., Davey, M., Lee, H., Wong, C. A., Lo, E., ... \& Stafford, E. (2010). Leadership styles and outcome patterns for the nursing workforce and work environment: a systematic review. International Journal of Nursing Studies, 47(3), 363-385. https://doi.org/10.1016/j.ijnurstu.2009.08.006

Dutta, V., \& Sahney, S. (2016). School leadership and its impact on student achievement: The mediating role of school climate and teacher job satisfaction. International Journal of Educational Management, 30(6), 941-958. https://doi.org/10.1108/IJEM-12-2014-0170

Eğriboyun, D. (2015). Ortaöğretim okullarında görev yapan yönetici ve öğretmenlerin liderlik uygulamaları ve iş 
doyumu algıları arasındaki ilişki [The relationship between high school administrators' and teachers' leadership practices and job satisfaction]. Gaziantep University Journal of Social Sciences, 14(1), 241-275.

Ereş, F., \& Akyürek, M., İ. (2016). İlkokul müdürlerinin dağıtılmış liderlik davranışları ile öğretmenlerin iş doyumu algıları arasındaki ilişki düzeyleri [The relationship between elementary school principals' distributed leadership behaviours and teachers' job satisfaction]. Gazi Üniversitesi Gazi Eğitim Fakültesi Dergisi, 36(3), 427-449.

Eriksen, M. (2009). Authentic leadership: Practical reflexivity, self-awareness, and self-authorship. Journal of Management Education, 33(6), 747-771. https://doi.org/10.1177/1052562909339307

Evans, L. (2001). Delving deeper into morale, job satisfaction and motivation among education professionals: Re-examining the leadership dimension. Educational Management \& Administration, 29(3), 291-306. https://doi.org/10.1177/0263211X010293004

Friedkin, N. E., \& Slater, M. R. (1994). School leadership and performance: A social network approach. Sociology of Education, 139-157.

Germain, M. L. (2012). Traits and skills theories as the nexus between leadership and expertise: Reality or fallacy? Performance Improvement, 51(5), 32-39. https://doi.org/10.1002/pfi.21265

Griffith, J. (2004). Relation of principal transformational leadership to school staff job satisfaction, staff turnover, and school performance. Journal of Educational Administration, 42(3), 333-356. https://doi.org/10.1108/09578230410534667

Güngör, S.K. (2016). The prediction power of servant and ethical leadership behaviours of administrators on teachers' job satisfaction. Universal Journal of Educational Research, 4(5), 1180-1188. https://doi.org/10.13189/ujer.2016.040531

Haj, S., J., \& Jubran, A. M. (2016). The extent of principals' application of the transformational leadership and its relationship to the level of job satisfaction among teachers of Galilee Region. Journal of Education and Practice, 7(11), 114-119.

Hallinger, P. (2003). Leading educational change: Reflections on the practice of instructional and transformational leadership. Cambridge Journal of Education, 33(3), 329-352. https://doi.org/10.1080/0305764032000122005

Hallinger, P. (2005). Instructional leadership and the school principal: A passing fancy that refuses to fade away. Leadership and Policy in Schools, 4(3), 221-239. https://doi.org/10.1080/15700760500244793

Hallinger, P., \& Chen, J. (2015). Review of research on educational leadership and management in Asia: A comparative analysis of research topics and methods, 1995-2012. Educational Management Administration \& Leadership, 43(1), 5-27. https://doi.org/10.1177/1741143214535744

Hallinger, P., \& Heck, R. H. (1996). Reassessing the principal's role in school effectiveness: A review of empirical research, 1980-1995. Educational Administration Quarterly, 32(1), 5-44. https://doi.org/10.1177/0013161X96032001002

Hallinger, P., \& Leithwood, K. (1994). Introduction: Exploring the impact of principal leadership. School Effectiveness and School Improvement, 5(3), 206-218. https://doi.org/10.1080/0924345940050301

Hallinger, P., Bickman, L., \& Davis, K. (1996). School context, principal leadership, and student reading achievement. The Elementary School Journal, 96(5), 527-549. https://doi.org/10.1086/461843

Hariri, H., Monypenny, R., \& Prideaux, M. (2012). Principalship in an Indonesian school context: can principal decision-making styles significantly predict teacher job satisfaction? School Leadership \& Management, 32(5), 453-471. https://doi.org/10.1080/13632434.2012.723617

Hariri, H., Monypenny, R., \& Prideaux, M. (2016). Teacher-perceived principal leadership styles, decision-making styles and job satisfaction: how congruent are data from Indonesia with the Anglophile and Western literature? School Leadership \& Management, 36(1), 41-62. https://doi.org/10.1080/13632434.2016.1160210

Harris, A. (2002). Effective leadership in schools facing challenging contexts. School Leadership \& Management, 22(1), 15-26. https://doi.org/10.1080/13632430220143024a

Harris, A. (2004). Distributed leadership and school improvement: leading or misleading? Educational Management Administration \& Leadership, 32(1), 11-24. https://doi.org/10.1177/1741143204039297 
Harris, A., \& Spillane, J. (2008). Distributed leadership through the looking glass. British Educational Leadership, Management \& Administration Society (BELMAS), 22(1), 31-34. https://doi.org/10.1177/0892020607085623

Heck, R. H. (1992). Principals' instructional leadership and school performance: Implications for policy development. Educational Evaluation and Policy Analysis, 14(1), 21-34. https://doi.org/10.3102/01623737014001021

Heck, R. H., \& Hallinger, P. (2009). Assessing the contribution of distributed leadership to school improvement and growth in math achievement. American Educational Research Journal, 46(3), 659-689. https://doi.org/10.3102/0002831209340042

Hulpia, H., \& Devos, G. (2009). Exploring the link between distributed leadership and job satisfaction of school leaders. Educational Studies, 35(2), 153-171. https://doi.org/10.1080/03055690802648739

Hulpia, H., Devos, G., \& Rosseel, Y. (2009). The relationship between the perception of distributed leadership in secondary schools and teachers' and teacher leaders' job satisfaction and organizational commitment. School Effectiveness and School Improvement, 20(3), 291-317. https://doi.org/10.1080/09243450902909840

Kabadayı R. (1982). Okul müdürlerinin liderlik davranışları ile öğretmenlerin güdülenmesi. Yayımlanmamış Doktora Tezi. Hacettepe Üniversitesi Sosyal Bilimler Enstitüsü, Ankara.

Kadi, A. (2015). Investigating teachers' organizational socialization levels and perceptions about leadership styles of their principals. Journal of Education and Training Studies, 3(4), 101-109. https://doi.org/10.11114/jets.v3i4.837

Karadağ, E., Başaran, A., \& Korkmaz, T. (2009). İlköğretim okulu öğretmenlerinin algıladıkları liderlik biçimleri ile iş doyumları arasındaki ilişki [The relationship between primary school teachers' perceived leadership styles and job satisfaction]. Ballkesir Üniversitesi Sosyal Bilimler Enstitüsü Dergisi, 12(21), 32-45.

Kim, I., \& Loadman, W. E. (1994). Predicting teacher job satisfaction. Retrieved from https://files.eric.ed.gov/fulltext/ED383707.pdf

Kim, S. (2002). Participative management and job satisfaction: Lessons for management leadership. Public Administration Review, 62(2), 231-241. https://doi.org/10.1111/0033-3352.00173

Koh, W. L., Steers, R. M., \& Terborg, J. R. (1995). The effects of transformational leadership on teacher attitudes and student performance in Singapore. Journal of Organizational Behavior, 16(4), 319-333. https://doi.org/10.1002/job.4030160404

Korkmaz, M. (2007). Örgütsel sağlık üzerinde liderlik stillerinin etkisi [The effect of leadership styles on organisational health]. Kuram ve Uygulamada Eğitim Yönetimi Dergisi, 13(1), 57-91.

Kuoppala, J., Lamminpää, A., Liira, J., \& Vainio, H. (2008). Leadership, job well-being, and health effects-A systematic review and a meta-analysis. Journal of Occupational and Environmental Medicine, 50(8), 904-915. https://doi.org/10.1097/JOM.0b013e31817e918d

Lashley, C. (2007). Principal leadership for special education: An ethical framework. Exceptionality, 15(3), 177-187. https://doi.org/10.1080/09362830701503511

Leithwood, K. (1994). Leadership for school restructuring. Educational Administration Quarterly, 30(4), 498-518. https://doi.org/10.1177/0013161X94030004006

Leithwood, K., \& Jantzi, D. (2000). The effects of transformational leadership on organizational conditions and student engagement with school. Journal of Educational Administration, 38(2), 112-129. https://doi.org/10.1108/09578230010320064

Leithwood, K., \& Jantzi, D. (2005). A review of transformational school leadership research 1996-2005. Leadership and Policy in Schools, 4(3), 177-199. https://doi.org/10.1080/15700760500244769

Leithwood, K., Harris, A., \& Hopkins, D. (2008). Seven strong claims about successful school leadership. School Leadership and Management, 28(1), 27-42. https://doi.org/10.1080/13632430701800060

Leithwood, K., Menzies, T., Jantzi, D., \& Leithwood, J. (1996). School restructuring, transformational leadership and the amelioration of teacher burnout. Anxiety, Stress, and Coping, 9(3), 199-215. https://doi.org/10.1080/10615809608249402

Leithwood, K., Steinbach, R., \& Jantzi, D. (2002). School leadership and teachers' motivation to implement accountability policies. Educational Administration Quarterly, 38(1), 94-119. 
https://doi.org/10.1177/0013161X02381005

Lester, P. E. (1987). Development and factor analysis of the teacher job satisfaction questionnaire (TJSQ). Educational and Psychological Measurement, 47(1), 223-233. https://doi.org/10.1177/0013164487471031

Luthans, F. (2010). Organizational behavior: An evidence-based approach. United State: McGraw Hill.

Madenoğlu, C., Uysal, Ş., Sarıer, Y., \& Banoğlu, K. (2014). Okul müdürlerinin etik liderlik davranışları ile öğretmenlerin iş doyumlarının örgütsel bağlılıkla ilişkisi [The relationship between school principals' ethical leadership behaviours and teachers' job satisfaciton]. Kuram ve Uygulamada Ë̈itim Yönetimi Dergisi, 20(1), 47-69. https://doi.org/10.14527/kuey.2014.003

Marks, H. M., \& Printy, S. M. (2003). Principal leadership and school performance: An integration of transformational and instructional leadership. Educational Administration Quarterly, 39(3), 370-397. https://doi.org/10.1177/0013161X03253412

Nasra, M. A., \& Heilbrunn, S. (2016). Transformational leadership and organizational citizenship behavior in the Arab educational system in Israel: The impact of trust and job satisfaction. Educational Management Administration \& Leadership, 44(3), 380-396. https://doi.org/10.1177/1741143214549975

Nguni, S., Sleegers, P., \& Denessen, E. (2006). Transformational and transactional leadership effects on teachers' job satisfaction, organizational commitment, and organizational citizenship behavior in primary schools: The Tanzanian case. School Effectiveness and School Improvement, 17(2), 145-177. https://doi.org/10.1080/09243450600565746

Northouse, P. G. (2007). Leadership: Theory and practice. London: Sage Publications.

Nyenyembe, F. W., Maslowski, R., Nimrod, B. S., \& Peter, L. (2016). Leadership styles and teachers' job satisfaction in Tanzanian public secondary schools. Universal Journal of Educational Research, 4(5), 980-988. https://doi.org/10.13189/ujer.2016.040507

Oakley, A. (2002). Social science and evidence-based everything: the case of education. Educational Review, 54(3), 277-286. https://doi.org/10.1080/0013191022000016329

Özgözgü, S., \& Altunay, E. (2016). Yöneticilerin liderlik davranışlarının öğretmenlere yansıyan sonuçları: Bir meta-analiz çalışması. Manisa Celal Bayar Üniversitesi Sosyal Bilimler Dergisi, 14(4), 259-294. https://doi.org/10.18026/cbayarsos.282794.

Paletta, A., Alivernini, F., \& Manganelli, S. (2017). Leadership for learning: The relationships between school context, principal leadership and mediating variables. International Journal of Educational Management, 31(2), 98-117. https://doi.org/10.1108/IJEM-11-2015-0152

Parris, D. L., \& Peachey, J. W. (2013). A systematic literature review of servant leadership theory in organizational contexts. Journal of Business Ethics, 113(3), 377-393. https://doi.org/10.1007/s10551-012-1322-6

Ross, J. A., \& Gray, P. (2006). Transformational leadership and teacher commitment to organizational values: The mediating effects of collective teacher efficacy. School effectiveness and School Improvement, 17(2), 179-199. https://doi.org/10.1080/09243450600565795

Rost, J. C. (1993). Leadership development in the new millennium. Journal of Leadership Studies, 1(1), 91-110. https://doi.org/10.1177/107179199300100109

Salameh, K. M. (2011). Servant leadership practices among school principals in educational directorates in Jordan. International Journal of Business and Social Science, 2(22), 138-145.

Sayadi, Y. (2016). The effect of dimensions of transformational, transactional, and non-leadership on the job satisfaction and organizational commitment of teachers in Iran. Management in Education, 30(2), 57-65. https://doi.org/10.1177/0892020615625363

Silins, H. C. (1992). Effective leadership for school reform. Alberta Journal of Educational Research, 38(4), 317-334.

Silins, H. C. (1994). The relationship between transformational and transactional leadership and school improvement outcomes. School Effectiveness and School Improvement, 5(3), 272-298. https://doi.org/10.1080/0924345940050305

Skaalvik, E. M., \& Skaalvik, S. (2011). Teacher job satisfaction and motivation to leave the teaching profession: Relations with school context, feeling of belonging, and emotional exhaustion. Teaching and Teacher 
Education, 27(6), 1029-1038. https://doi.org/10.1016/j.tate.2011.04.001

Skakon, J., Nielsen, K., Borg, V., \& Guzman, J. (2010). Are leaders' well-being, behaviours and style associated with the affective well-being of their employees? A systematic review of three decades of research. Work \& Stress, 24(2), 107-139. https://doi.org/10.1080/02678373.2010.495262

Spector, P. E. (1997). Job satisfaction: Application, assessment, causes, and consequences. UK: Sage Publications.

Spillane, J. P., Halverson, R., \& Diamond, J. B. (2001). Investigating school leadership practice: A distributed perspective. Educational Researcher, 30(3), 23-28. https://doi.org/10.3102/0013189X030003023

Swaminathan, S., \& Jawahar, P. D. (2013). Job satisfaction as a predictor of organizational citizenship behavior: An empirical study. Global Journal of Business Research, 7(1), 71-80.

Taş, S. (2017). The effect of vocational high school administrators' leadership behaviors on teacher job satisfaction. Universal Journal of Educational Research, 5(11), 2092-2100. https://doi.org/10.13189/ujer.2017.051126

Tesfaw, T. A. (2014). The relationship between transformational leadership and job satisfaction: The case of government secondary school teachers in Ethiopia. Educational Management Administration \& Leadership, 42(6), 903-918. https://doi.org/10.1177/1741143214551948

Tok, T. N., \& Bacak, E. (2013). Öğretmenlerin iş doyumu ile yöneticileri için algıladıkları dönüşümcü liderlik özellikleri arasındaki ilişki [The relationship between teachers' job satisfaction and administrators' perceived transformational leadership characteristics]. International Journal of Human Sciences, 10(1), $1135-1166$.

Walumbwa, F. O., Hartnell, C. A., \& Oke, A. (2010). Servant leadership, procedural justice climate, service climate, employee attitudes, and organizational citizenship behavior: a cross-level investigation. Journal of Applied Psychology, 95(3), 517. http:// doi.org/10.1037/a0018867

Wang, G., Oh, I. S., Courtright, S. H., \& Colbert, A. E. (2011). Transformational leadership and performance across criteria and levels: A meta-analytic review of 25 years of research. Group \& Organization Management, 36(2), 223-270. https://doi.org/10.1177/1059601111401017

Weiss, D. J., Dawis, R. V., England, G. W., \& Lofquist, L. H. (1967). Manual for the Minnesota satisfaction questionnaire. Minneapolis: University of Minnesota Industrial Relations Center.

Yılmaz, A., \& Ceylan, Ç. B. (2011). İlköğretim okul yöneticilerinin liderlik davranış düzeyleri ile öğretmenlerin iş doyumu ilişkisi [Primary school administrators' leadership behaviour levels and teachers' job satisfaction]. Kuram ve Uygulamada Ĕ̈itim Yönetimi Dergisi, 17(2), 277-394.

Yilmaz, E. (2010). The analysis of organizational creativity in schools regarding principals' ethical leadership characteristics. Procedia-Social and Behavioral Sciences, 2(2), 3949-3953.

Yılmaz, K., \& Altınkurt, Y. (2012). Relationship between the leadership behaviors, organizational justice and organizational trust. Çukurova University Faculty of Education Journal, 41(1), 12.

Yukl, G. (1989). Managerial leadership: A review of theory and research. Journal of Management, 15(2), 251-289. https://doi.org/10.1177/014920638901500207

Zhang, Z., Lee, J. C., \& Wong, P. H. (2016). Multilevel structural equation modeling analysis of the servant leadership construct and its relation to job satisfaction. Leadership \& Organization Development Journal, 37(8), 1147-1167. https://doi.org/10.1108/LODJ-07-2015-0159 


\section{Appendix A}

\section{Brief Findings Reported in the Studies Examined}

\begin{tabular}{lll}
\hline & Authors & Findings \\
\hline $\mathbf{1}$ & Korkmaz (2007) & School principals' transformational leadership styles positively and strongly predict teachers' job satisfaction \\
& & $(\beta=.56, p<.05)$. Interactional leadership is not related to job satisfaction $(p>.001)$.
\end{tabular}

$3 \quad \begin{array}{lll}\text { Karadağ, } & \text { Başaran } & \text { Transformational leadership is positively and significantly related to overall job satis } f a c \\ \text { and Korkmaz }(2009) & \text { intrinsic job satisfaction }(r=.34, \mathrm{p}<.01) \text {, and extrinsic job satisfaction }(\mathrm{r}=.73, \mathrm{p}<.01) \text {. }\end{array}$

Transactional leadership is positively and significantly related to overall job satisfaction $(r=.30, \mathrm{p}<.01)$, intrinsic job satisfaction $(r=.17, \mathrm{p}<.01)$, and extrinsic job satisfaction $(\mathrm{r}=.39, \mathrm{p}<.01)$.

4 Tok and Bacak There is a positive and significant relationship between transformational leadership and job satisfaction ( $r=.14$, (2013) $\mathrm{p}<.01)$. The highest level of relationship is between inspirational motivation and job satisfaction $(r=.21$, $\mathrm{p}$ $<.01)$. The positive and significant relationships between idealised effect, motivation, intellectual stimulation, individual support and job satisfaction are at a lower level than with inspirational motivation.

5 Bogler (2001) Teachers' job satisfaction is positively and significantly related to transformational leadership $(r=.56$, $\mathrm{p}$ $<.0001)$ and participative leadership $(r=.35, \mathrm{p}<.01)$, while being negatively and significantly related to interactional leadership $(r=-.21, \mathrm{p}<.01)$,

School principals' transformational leadership styles directly affect teachers' job satisfaction $(\beta=.16$, $p<.0001)$. Interactional leadership style negatively and significantly predict job satisfaction $(\beta=-.13$, $P<.0001)$. Participative leadership is related to job satisfaction $(r=.35, p<.0001)$.

\begin{tabular}{lll}
\hline & $\begin{array}{l}\text { Dutta and Sahney } \\
\text { (2016) }\end{array}$ & \\
\hline 7 & Griffith (2004)
\end{tabular}
Transformational leadership does not predict teachers' job satisfaction.

Teachers' job satisfaction predicts job satisfaction through an effective school culture $(\beta=.027, p<.001)$.

7 Griffith (2004) Transformational leadership positively predict teachers' job satisfaction $(\beta=.88, p<.001)$. All subdimensions of transformational leadership contribute to transformational leadership at high levels (standard $\beta>.90$ ).

\begin{tabular}{ll}
\hline $\mathbf{8}$ & $\begin{array}{l}\text { Haj and Jubran } \\
(2016)\end{array}$ \\
\hline $\mathbf{9}$ & $\begin{array}{l}\text { Nasra and Heilbrunn } \\
(2016)\end{array}$ \\
\hline $\mathbf{1 0}$ & Sayadi (2016)
\end{tabular}

Transformational leadership is related to job satisfaction $(r=.89, p<.001)$.

Transformational leadership behaviours are related to job satisfaction $(r=.68, p<.005)$ and predict it $(\beta=.76$, $p<.005)$.

Teachers' job satisfaction is positively and significantly related to charisma $(r=.44, p<.001)$, individual interest $(r=.35, \mathrm{p}<.001)$, and intellectual stimulation $(r=.29, p<.001)$. All subdimensions of transformational leadership and job satisfaction are positively and significantly related.

Job satisfaction is positively and significantly related to conditional rewards $(r=.23, p<.001)$ while being negatively and significantly related to Laissez-Faire leadership $(r=-.24, p<.001)$. There are not significant relationships between job satisfaction and management with exceptions (active or passive).

The regression analysis shows that the most significant predictor of job satisfaction is charisma $(\beta=.020$, $p<.001)$.

11 Teswaf (2014) Transformational leadership is positively and significantly related to teachers' job satisfaction ( $r=.47$, $p<.001)$. Extrinsic $(r=.45, p<.001)$ and intrinsic job satisfaction $(r=.40, p<.001)$ are positively and significantly related to transformational leadership.

Idealised effect (attributed) and inspirational motivation, transformational leadership characteristics, predict overall job satisfaction. Idealised effect $\left(\mathrm{R}^{2}=.22\right)$ explains job satisfaction at a higher level compared to inspirational motivation $\left(\mathrm{R}^{2}=.013\right)$.

All subdimensions of transformational leadership and job satisfaction are positively and significantly related. The strongest relationship is between idealised effect (attributed) and job satisfaction $(r=.49)$, and the lowest relationship is with intellectual stimulation $(r=.37)$

12 Hariri, Monypenny Transformational leadership characteristics predict teachers' job satisfaction $(\beta=.26, p<.005)$. Laissez-Faire and Prideaux (2016) leadership negatively predict teachers' job satisfaction $(\beta=.11, p<.005)$. School administrators' rational decision-making strategies predict job satisfaction $(\beta=.26, p<.005)$. As intuitive decision-making $(\beta=-.14$, $p<.005)$ and avoidant decision-making $(\beta=-.23, p<.005)$ increase, job satisfaction increases.

13 Nguni, Sleegers and While transformational leadership explain $15 \%$ of the variation in job satisfaction, the explanatory power of Denessen (2006) interactional leadership is $4 \%$. Charisma has the highest predictive level $(\beta=.38, p<.005)$ and it is followed by conditional rewards $(\beta=.14, p<.005)$. Intellectual stimulation $(\beta=.11, p<.005)$ and management with exceptions (passive) $(\beta=.10, p<.005)$ predict job satisfaction.

\begin{tabular}{lll}
14 & Kadi (2015) & Transformational leadership is positively and significantly related to job satisfaction $(r=.44, p<.05)$. \\
& & $\begin{array}{l}\text { Interactional leadership and job satisfaction are positively and significantly related }(r=.61, p<.05) . \\
\text { Laissez-Faire leadership and job satisfaction are negatively and significantly related }(r=-.19, p<.05) .\end{array}$ \\
\hline $\mathbf{1 5}$ & $\begin{array}{l}\text { Nyenyembe, } \\
\text { Maslowski, Nimrod } \\
\text { and Peter (2016) }\end{array}$ & $\begin{array}{l}\text { Charismatic leadership predicts teachers' job satisfaction }(\beta=.28, p<.005) . \text { Individual interest predicts job } \\
\text { satisfaction }(\beta=.12, p<.005) . \text { Management with exceptions (passive) negatively predicts teachers' job } \\
\text { satisfaction }(\beta=-.08, p<.005) . \text { Charismatic leadership and job satisfaction are positively and significantly } \\
\text { related }(r=.73, p<.05) .\end{array}$ \\
\hline $\mathbf{1 6}$ & Y1lmaz and Ceylan & $\begin{array}{l}\text { Administrators' leadership behaviours are positively and significantly related to teachers' job satisfaction } \\
(r=.49, p<.05) .\end{array}$ \\
\hline $\mathbf{1 7}$ & Paletta et al. (2017) & School leadership predicts teachers'job satisfaction $(\beta=.50, p<.005)$. \\
\hline
\end{tabular}




\begin{tabular}{|c|c|c|}
\hline 18 & Taş (2017) & $\begin{array}{l}\text { Job satisfaction is positively and significantly related to organisation-oriented leadership }(r=.73, p<.05) \text {, } \\
\text { individual-oriented leadership }(r=.77, p<.05) \text { and change-oriented leadership }(r=.73, p<.05) \text {. } \\
\text { Individual-oriented leadership is the only predictor of job satisfaction }(\beta=.51, p<.005) \text {. }\end{array}$ \\
\hline 19 & $\begin{array}{l}\text { Hulpia, Devos and } \\
\text { Rosseel (2009) }\end{array}$ & $\begin{array}{l}\text { Team cohesion }(\beta=.12, p<.001) \text { and supportive leadership }(\beta=.18, p<.001) \text { predict job satisfaction, but } \\
\text { participative decision-making is not a predictor. Supportive leadership predicts job satisfaction }(\beta=.078 \text {, } \\
p<.001) \text {. }\end{array}$ \\
\hline 20 & $\begin{array}{l}\text { Hariri, Monypenny } \\
\text { and Prideaux (2012) }\end{array}$ & $\begin{array}{l}\text { School administrators' rational decision-making strategies predict job satisfaction }(\beta=.35, p<.005) \text {. As } \\
\text { intuitive decision-making }(\beta=-.16, p<.005) \text { and avoidant decision-making }(\beta=-.30, p<.005) \text { increase, job } \\
\text { satisfaction increases. Dependent decision-making predicts job satisfaction }(\beta=.12, p<.005) \text {. } \\
\text { Job satisfaction is positively and significantly related to dependent decision-making }(r=.19, p<.05) \text {. Job } \\
\text { satisfaction is negatively and significantly related to intuitive decision-making }(r=-.42 p<.05) \text {, avoidant } \\
\text { decision-making }(r=-.50, p<.05) \text {, spontaneous decision-making }(r=-.19, p<.05) \text {. }\end{array}$ \\
\hline 21 & $\begin{array}{l}\text { Ereş and Akyürek } \\
(2016)\end{array}$ & $\begin{array}{l}\text { There are positive relationships between job satisfaction, and strong vision }(r=, 53) \text {, supportive leadership } \\
(r=, 66) \text {, instructional support }(r=, 65) \text { and supervision }(r=, 61) \text {. } \\
\text { There are also positive relationships between job satisfaction, and role ambiguity }(r=, 75) \text {, group cohesion } \\
(r=, 77) \text { and degree of consensus }(r=, 70) \text {. }\end{array}$ \\
\hline 22 & $\begin{array}{l}\text { Zhang, Lee } \\
\text { Wong (2016) }\end{array}$ & $\begin{array}{l}\text { School administrators' servant leadership behaviours predict teachers' job satisfaction }(\beta=.47, p<.005) \text { and } \\
\text { explain } 22 \% \text { of the variation in job satisfaction. }\end{array}$ \\
\hline 23 & Cerit (2009) & $\begin{array}{l}\text { Teachers' intrinsic job satisfaction }(r=.59, p<.05) \text { and extrinsic job satisfaction }(r=.57, p<.05) \text { are related to } \\
\text { servant leadership. All dimensions of servant leadership are positively and significantly related to job } \\
\text { satisfaction }(\mathrm{r}>.42) \text {. } \\
\text { Servant leadership behaviours explain } 58 \% \text { of the variation in teachers' job satisfaction. Valuing individuals, } \\
\text { developing their skills, forming a community, acting authentically and enhancing leadership are predictors of } \\
\text { job satisfaction. Acting authentically is a strong predictor of intrinsic and extrinsic job satisfaction. }\end{array}$ \\
\hline 24 & $\begin{array}{l}\text { Al-Mahdy, Al-Harti } \\
\text { and El-Din, 2016) }\end{array}$ & $\begin{array}{l}\text { Teachers' job satisfaction are positively and significantly related to administrators' servant leadership } \\
\text { behaviours }(p<.001) \text {. Among the servant leadership behaviours, the strongest relationship with job satisfaction } \\
\text { is in supervision (improving team skills) }(\mathrm{r}>.32) \text {. The relationships with support and nature of the job are } \\
\text { weaker compared to supervision. }\end{array}$ \\
\hline 25 & Güngör (2016) & $\begin{array}{l}\text { Administrators' ethical leadership behaviours are positively and significantly related to teachers' job } \\
\text { satisfaction }(r=.44, p<.01) \text {. Ethical leadership predicts teachers' job satisfaction }(\beta=.30, p<.01) \text {. }\end{array}$ \\
\hline 26 & $\begin{array}{l}\text { Madenoğlu, Uysal, } \\
\text { Sarıer and Banoğlu } \\
(2014)\end{array}$ & $\begin{array}{l}\text { Administrators' ethical leadership behaviours are positively and significantly related to teachers' job } \\
\text { satisfaction }(r=.57, p<.01) \text {. Ethical leadership predicts teachers' job satisfaction }(\beta=.43, p<.01) \text {. }\end{array}$ \\
\hline 27 & $\begin{array}{l}\text { Cetin and Özcan } \\
(2004)\end{array}$ & $\begin{array}{l}\text { cal leadership behaviours are positively and significantly related to teachers' job } \\
p<.01) \text {. }\end{array}$ \\
\hline
\end{tabular}

\section{Copyrights}

Copyright for this article is retained by the author(s), with first publication rights granted to the journal.

This is an open-access article distributed under the terms and conditions of the Creative Commons Attribution license (http://creativecommons.org/licenses/by/4.0/). 